\title{
Impact of non nutritional factors on milk urea concentration and its relationship with production and fertility traits in Vojvodina dairy herds
}

doi: 10.15567/mljekarstvo.2017.0404

\author{
Ksenija Čobanović ${ }^{*}$, Denis Kučević ${ }^{1}$, Miroslav Plavšić ${ }^{1}$, Vladan Bogdanović ${ }^{2}$ \\ ${ }^{1}$ University of Novi Sad, Faculty of Agriculture, Trg Dositeja Obradovića br. 8, 21000 Novi Sad, Serbia \\ ${ }^{2}$ University of Belgrade, Faculty of Agriculture, , Nemanjina 6, 11080, Beograd - Zemun, Serbia
}

Received - Prispjelo: 24.04.2017.

Accepted - Prihvaćeno: 27.09.2017.

\begin{abstract}
The purpose of this study was to examine possible relationship between milk urea and fertility of dairy cows using field data. This study also evaluated the influence of environmental factors on milk urea (MU) and the relationship between MU and daily milk yield, milk fat and protein percentage. The data were collected at 11 dairy farms in the Vojvodina region. Reproductive data and MU measurements were obtained from cows that calved between June 2013 and October 2015 and had a successful conception after calving. Statistical data processing was carried out by applying General Linear Model procedure, Statistics 13. Parity, calving season, season of milk control and farm were included in the models as fixed effects. Significant differences in MU concentrations were observed between farms $(\mathrm{P}<0.01)$, seasons $(\mathrm{P}<0.01)$ and parity $(\mathrm{P}<0.05)$. Highly significant $(\mathrm{P}<0.01)$ positive relationships were found between $\mathrm{MU}$ concentration and milk yield, fat and protein percentage and days open. Cows with MU levels below $10 \mathrm{mg} \mathrm{dL}^{-1}$ had the lowest day open interval (135.59 days) and cows with MU higher than $35 \mathrm{mg} \mathrm{dL}^{-1}$ had the longest days open interval (163.18 days). The cows with the lowest mean MU values $\left(<10 \mathrm{mg} \mathrm{dL}^{-1}\right)$, had the shortest days open interval (72.62 days), but cows with mean MU values between $20.01-25.00 \mathrm{mg} \mathrm{dL}^{-1}$ had the longest days open interval (161.78 days). Results of this study indicate that increased MU levels appear to have a negative effect on dairy cow fertility.
\end{abstract}

Key words: milk urea, dairy cows, days open, season, parity

\section{Introduction}

Urea as a part of the non-protein fraction of nitrogen in milk and represents the final product of protein metabolism in the rumen of ruminants. Toxic ammonia comes into the liver by portal bloodstream and undergoes there the transformation to urea, which comes later into milk by bloodstream. Thus, urea content can be determined in the bloodstream and in milk (Rajala-Schultz et al., 2001). When milk samples are taken as part of regular Dairy Herd Improvement (DHI) testing, sampling for MU testing involves no extra labor, and it is cheaper than sampling and analysing blood. Nutrition and content of crude proteins in the diet have the greatest influence on the milk urea content (Broderick and Clayton, 1997; Godden et al., 2001). Milk urea nitrogen (MUN) can be used as a tool to monitor protein feeding efficiency and dietary protein - energy ratio in dairy cows (Hof et al., 1997, Eicher et al., 1999).

Apart from feeding, milk urea content can be affected by some other factor such as season (Godden et al., 2001; Hojman et al., 2004; Fatehi et al., 2012), milk yield (Godden et al., 2001; Arunvipas et al., 2003; Hojman et al., 2005), stage 
of lactation (Moore and Varga, 1996; Godden et al., 2001; Rajala-Schultz and Saville, 2003; Fatehi et al., 2012), parity (Godden et al., 2001; Arunvipas et al., 2003; Wood et al., 2003; Hojman et al., 2004;), breed (Rodriguez et al., 1997; Wattiaux et al., 2005), body weight (Jonker et al., 2002; Hojman et al., 2005), etc.

Fertility is the major contributor to profitability of the dairy herd and is a trait with a very low heritability value (Melendez et al., 2000). Selection for greater milk yield in dairy cattle has led to a decline in fertility due to antagonistic genetic correlations between production and reproduction traits (Pryce et al., 2004). In recent decades, a decline in dairy herd reproductive efficiency has been reported from different parts of the world (Lopez-Gatius, 2003; Rajala-Schultz and Frazer, 2003; de Vries and Risco, 2005; Löf et al., 2007; Ferguson and Skidmore, 2013).

A great number of factors influence the fertility of cows. Nutritional management plays one of the most important roles in achieving reproductive goals (Ferguson and Chalupa, 1989). High dietary protein intake stimulates milk production but has also been associated with decreased fertility (Elrod and Butler, 1993; Westwood et al., 1998; Butler, 2005). Cows fed with excess dietary protein showed increased blood urea, altered uterine fluid composition, decreased uterine $\mathrm{pH}$ and reduced conception rates (Ferguson and Chalupa, 1989).

Some studies reported a negative effect of high MUN on fertility in dairy cattle (Gustafsson and Carlson, 1993; Elrod and Butler, 1993; Butler et al., 1996; Larson et al., 1997; Wittwer et al., 1999; Rajala-Schultz et al., 2001). Butler (2005) reported that $\mathrm{MU}$ levels $>19 \mathrm{mg} \mathrm{dL}^{-1}$ had been associated with reduced reproductive performance. However, other studies (Howard et al., 1987; Garcia-Bojalil et al., 1998; Melendez et al., 2000; Godden et al, 2001; Kenny et al., 2002) have not found any negative effects of MUN on fertility.

Disagreement among the above studies might partially come from differences in study design. Most of those studies were experimental under highly controlled management, and used relatively small sample sizes. Therefore, it can not be representative of commercial dairy herds under a variety of feeding.
The objectives of this study were to identify and evaluate environmental factors that influence MU in Vojvodina dairy herds and to determine relationship of MUN with 3 milk production traits, milk yield (MY), milk fat (\%) and protein (\%), as well as to investigate relationship between MU and days open (DO - from calving to last insemination).

\section{Materials and methods}

The study included 4057 Holstein cows originating from 11 Vojvodina dairy farms. Lactation of tested cows started during the study period (between June 2013 and October 2015), whereby the information on their parity, calving dates and insemination date were delivered too. Feeding by total mixed ration were applied at all investigated farms based on maize and lucerne silage, lucerne hay, concentrates feed (home-grown grains) and mineral supplements. Chemical composition of the applied diets was formulated according to the NRS standard and adjusted to cow's lactation groups (assigned to milk yield). The conception date was recorded as the last insemination before pregnancy was confirmed. Sampling of each cow's milk started after calving. All samples in this study were taken once a day, during the normal milking time. Milk recording control was performed by AT4 method (ICAR, 2014). Milk samples were collected from June 2013 to December 2015 in the bottles $(40 \mathrm{~mL})$ with preservatives (potassium dichromate), cooled at $4{ }^{\circ} \mathrm{C}$ and transported to the Laboratory for milk quality control in Novi Sad. The laboratory is accredited in accordance with the international standard, ISO 17025 and ICAR guidelines (2014).

Milk urea and chemical composition were determined by the infrared test method (ISO 9622:2013) by Milcoscan FT. Extreme values of particular parameters were not analysed in the following cases: MU concentration $<7$ and $>90 \mathrm{mg} \mathrm{dL}$ ${ }^{1}$; milk fat content $<2 \%$ and $>6 \%$ and protein $<2 \%$ and $>5 \%$. To convert MU to MUN, the following conversion formula can be used: $\mathrm{MUN}\left(\mathrm{mg} \mathrm{dL}^{-1}\right)=$ MU (mg dL-1) x 0.4667 (Oudah, 2009). The complete dataset consisted of 45,316 individual cow records from Dairy Herd Improvement monthly test, that included date of test (season), daily milk yield, 
milk fat content, milk protein content, MU and days in milk. Also the day of calving and the day of last insemination were collected, days open were calculated. Dairy cows in Vojvodina dairy farms are regularly inseminated by AI technicians. Pregnancy diagnosis is performed by herd veterinarians approximately 45 $\mathrm{d}$ after insemination by per rectum palpation.

According to the season of calving and sampling, milk samples were divided into four groups:

1 - winter (December-February),

2 - spring (March - May),

3 - summer (June - August) and

4 - autumn (September - November).

For the analysis parity cows were grouped in three categories (first, second and third + ).

\section{Statistical analysis}

The average values and variability of examined traits as well as the effect of factors on mentioned traits were studied by means of the PROC UNIVARIATE and PROC GLM procedures within the Statistica software package (ver. 13 StatSoft Company, 2016). Post-hoc analysis (Duncan test) was used to determine the statistically significant differences between the mean values of different classes of AFC and as the main fixed factors in the study, with a significance level $\mathrm{P}<0.05$ and $\mathrm{P}<0.01$. Three models were designed.

Model 1a examined influence of farm, parity and season of sampling on MU concentrations and production variables (daily milk yield - DMY, milk fat - MF and protein - P).

The data were subjected to the analysis of variance using the following model:

$$
\begin{aligned}
\mathrm{Y}_{\mathrm{ijk}}= & \mu+\mathrm{F}_{\mathrm{i}}+\mathrm{P}_{\mathrm{j}}+\mathrm{S}_{\mathrm{k}+} \mathrm{e}_{\mathrm{ijk}} \\
\mathrm{Y}_{\mathrm{ijk}}= & \mathrm{MU}, \mathrm{MF}, \mathrm{P} \text { and DMY (dependent } \\
& \text { variable) } \\
\mu= & \text { mean value of dependent variable } \\
\mathrm{F}_{\mathrm{i}}= & \text { farm, } \mathrm{i}=1(\text { Farm } 1), 2 \text { (Farm } 2), \ldots \text { and } 11 \\
& (\text { Farm } 11) \\
\mathrm{P}_{\mathrm{j}}= & \text { parity, } \mathrm{j}=1^{\text {st }}, 2^{\text {nd }} \text { and } 3^{\text {rd }}+, \\
\mathrm{S}_{\mathrm{k}}= & \text { season of sampling, } \mathrm{k}=1,2,3 \text { and } 4, \\
\mathrm{e}_{\mathrm{ijk}}= & \text { other random effects }
\end{aligned}
$$

Model $1 b$ examined influence of farm, parity and season of calving on days open (DO).
The data were subjected to the analysis of variance using the following model:

$$
\begin{aligned}
& \mathrm{Y}_{\mathrm{ijk}}=\mu+\mathrm{F}_{\mathrm{i}}+\mathrm{P}_{\mathrm{j}}+\mathrm{S}_{\mathrm{k}+} \mathrm{e}_{\mathrm{ijk}} \\
& \mathrm{Y}_{\mathrm{ijk}}=\text { DO (dependent variable) } \\
& \mu=\text { mean value of dependent variable } \\
& \left.\mathrm{F}_{\mathrm{i}}=\text { farm, } \mathrm{i}=1(\text { Farm } 1), 2 \text { (Farm } 2\right), \ldots \text { and } 11 \\
& \quad(\text { Farm } 11) \\
& \mathrm{P}_{\mathrm{j}}=\text { parity, } \mathrm{j}=1^{\text {st }}, 2^{\text {nd }} \text { and } 3^{\text {rd }}+, \\
& \mathrm{S}_{\mathrm{k}}=\text { season of calving, } \mathrm{k}=1,2,3 \text { and } 4, \\
& \mathrm{e}_{\mathrm{ijk}}=\text { other random effects }
\end{aligned}
$$

Model 2 analysed the production variables (daily milk yield, milk fat and protein) in different MU groups. All data were divided in seven MU

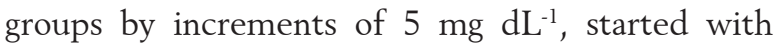
those less than $10 \mathrm{mg} \mathrm{dL}^{-1}$ and finished with concentration greater than $35 \mathrm{mg} \mathrm{dL}^{-1}$. The Duncan test was used to determine statistically significant differences between the mean values of different groups, with a significance level $\mathrm{P}<0.05$ and $\mathrm{P}<0.01$.

Model 3 analysed in two ways the effects of MU on days open.

In the first way all cows were divided in seven MU groups by increments of $5 \mathrm{mg} \mathrm{dL}^{-1}$, started with those less than $10 \mathrm{mg} / \mathrm{dL}$ and finished with concentration greater than $35 \mathrm{mg} \mathrm{dL}^{-1}$, based on MU value on monthly control the closest the breeding date.

In the second way the means of monthly MU values for each cow from calving up to the time of the last insemination were used in the modeling to reflect cows MU status before the conception. Cows were categorized into seven groups based on mean MU values before the last insemination: I Group $<10 \mathrm{mg} \mathrm{dL}^{-1}$, II group 10.01-15.00 $\mathrm{mg} \mathrm{dL}^{-1}$, III group $15.01-20.00 \mathrm{mg} \mathrm{dL}^{-1}$, IV group 20.01-25.00 $\mathrm{mg} \mathrm{dL}^{-1}$, $\mathrm{V}$ group 25.01-30.00 $\mathrm{mg} \mathrm{dL}^{-1}$, VI group 30.01$35.00 \mathrm{mg} \mathrm{dL}^{-1}$ and VII group $>35 \mathrm{mg} \mathrm{dL}^{-1}$. Some cows had only one measurement and the maximum number of MU measurements for a cow during the study period were 11 . The Duncan test was used to determine statistically significant differences between the mean values of different groups, with a significance level $\mathrm{P}<0.05$ and $\mathrm{P}<0.01$.

Finally, the analysis of correlation between MU concentration and production variables and days open was performed using the correlation procedure (Statistic. 13). For all parameters, model effects were declared significant at $\mathrm{P}<0.05$ and $\mathrm{P}<0.01$. 


\section{Results and discussion}

The average results for milk urea concentration (MU), milk fat and total protein percentages, daily milk yield (DMY) and days open (DO) are presented in Table 1 .

The mean MU concentration was $25.18 \mathrm{mg} \mathrm{dL}^{-1}$ (with standard deviation of 8.60) and was within the optimal values from 15 to $30 \mathrm{mg} \mathrm{dL}^{-1}$ (Carlson and Pehrson, 1993; Moore and Varga, 1996). Average cow - level MU concentration was higher than the values reported in studies of Hof et al. (1997) and Kohn et al. (2004), but lower than the values reported by Wood et al. (2003), Wattiaux and Karg (2004), Zadeh-Hossein and Ardalan (2011) and Fatehi et al. (2012) for Holstein dairy cows.

The coefficient of variation for the milk urea content $(34.15 \%)$ was higher than the coefficient of variation for the other milk production traits. Stoop et al. (2007), Bastin et al. (2009), Bouwman et al. (2010), Zadeh-Hossein and Ardalan (2011) and Čobanović et al. (2015) also found higher CV for MU than other milk ingredients.

Mean values for milk fat $(3.78 \%)$ and protein contents $(3.29 \%)$ determined in this study were somewhat higher than average values for total Holstein population in Vojvodina in 2015 year (milk fat $3.71 \%$, protein $3.25 \%$, total milk yield $9,177 \mathrm{~kg}$ ) given by Main breeding organization (2016).

The mean of days open was 152.10 days and longer than the optimal interval of 90 days (Stančić, 1988). Many studies have reported that in the past few decades the days open interval increased for Holstein cows. Washburn et al. (2002) adduced that days open for Holstein dairy cows were 166 days, Ferguson and Skidmore (2013) reported the interval of 150 days and Nêmečková et al. (2015) determined the days open interval between 144 and 182 days.
The influence of the farm was included in the model as a fixed effect to account for the different management factors and feeding regimens. As expected, management of the farm had great influence on the content of milk urea and other examined parameters (Table 2).

The $\mathrm{F}$ values were significant in all cases showing the important influence of farms on the examined variables (fat, protein, DMY, MU, DO). The highest content of MU, $29.91 \mathrm{mg} \mathrm{dL}^{-1}$, was found on Farm 3. On the contrary, the lowest MU content was estimated on Farm 2 (22.39 $\left.\mathrm{mg} \mathrm{dL}^{-1}\right)$. The effect of farm on MU and other examined parameters is related to the different ratio of energy and protein in feeding ratio. Statistically significant differences in the MU content between farms were reported by others (Carlson et al., 1995; Rajala-Schultz and Saville, 2003; Wattiaux et al., 2005; Konjačić et al., 2006; Jilek et al., 2006; Bastin et al., 2009).

The content of milk fat, protein, MU and daily milk yield were significantly influenced by the number of lactations (Table 3). Parity did not influence the days open interval.

The high values of the F- ratios are the proof of the important influence of the parity on the examined variables.

Higher MU concentration (25.26 $\left.\mathrm{mg} \mathrm{dL}^{-1}\right)$ was found in cows in the first lactation. The mean MU concentration of cows in the third and greater lactation $\left(25.04 \mathrm{mg} \mathrm{dL}^{-1}\right)$ was lower than in the first and second lactation. The overall differences between lactations are numerically small. Godden et al. (2001), Johnson and Young (2003) and Jilek et al. (2006) also recorded the highest MUN concentration in cows in the first lactation, with significant results in overall means, but numerically small difference between lactations. Jonker et al. (1998) used models to predict changes in MUN due to parity and suggested that the first lactation

Table 1. Means, standard deviation (SD) and coefficient of variation (CV) of analyzed variables

\begin{tabular}{ccccc}
\hline Trait & $\mathrm{N}$ & Mean & SD & CV (\%) \\
\hline MU (mg/dL) & 46315 & 25.18 & 8.60 & 34.15 \\
\hline MUN (mg/dL) & 46315 & 11.76 & 4.01 & 34.15 \\
\hline Fat (\%) & 46315 & 3.78 & 0.87 & 23.09 \\
\hline Protein (\%) & 46315 & 3.29 & 0.42 & 12.68 \\
\hline DMY (kg) & 46315 & 27.11 & 9.98 & 36.81 \\
\hline Days open & 4057 & 152.10 & 79.81 & 52.47 \\
\hline
\end{tabular}


animals would have a higher MUN than mature animals. Contrary to our results, Oltner et al. (1985), Carroll et al. (1988), Arunvipas et al. (2003) and Hojman et al. (2004) found lower MUN content in the first lactation cows than the second or later lactation animals. Other studies did not find parity effect (Kaufmann, 1982; Carlsson et al., 1995; Eicher et al., 1999). We do not have an explanation for the differences between lactation in MU content.

Cows in the first lactation had a higher milk fat content $(3.80 \%)$ and cows in the second lactation had a higher protein content $(3.31 \%)$ and daily milk yield $(28.15 \mathrm{~kg})$.

Days open interval was not influenced by parity. The longest days open interval had cows in third and greater lactation (153.36 days) and was shorter for cows in the second lactation (150.94 days). These differences were not significant and similar results were found by Rajala-Schultz et al. (2001) and Mitchell et al (2005).
According to the data in Table 4, season had a significant effect on MU concentration in Holstein cows and other examined traits (the values of F-test in all cases are highly significant). Milk urea nitrogen was lower in autumn $\left(22.19 \mathrm{mg} \mathrm{dL}^{-1}\right)$ and the highest during summer $\left(27.11 \mathrm{mg} \mathrm{dL}^{-1}\right)$. Similar results have been reported by: Hojman et al. (2004), Abdouli et al. (2008), Bastin et al., (2009) and Fatehi et al. (2012). Higher MUN concentration in the winter period was reported by Jilek et al. (2006).

Calving season significantly influenced the days open interval. The shortest days open interval had cows that calved in summer period, probably because their successful conception was in autumn and winter period, and they avoided heat stress. Melendez et al. (2000) and Rajala-Schultz et al. (2001) also found that calving season had a greater effect on pregnancy rate.

Table 2. Effect of farm on milk fat and protein content, daily milk yield, milk urea concentration and days open

\begin{tabular}{ccccccc}
\hline Farm & $\mathrm{N}$ & Fat $(\%)$ & Protein $(\%)$ & DMY $(\mathrm{kg})$ & MU $\left(\mathrm{mg} \mathrm{dL}^{-1}\right)$ & DO (days) \\
\hline $\mathrm{l}$ & 10124 & $3.88^{\mathrm{a}}$ & $3.33^{\mathrm{a}}$ & $24.22^{\mathrm{a}}$ & $23.01^{\mathrm{a}}$ & $161.71^{\mathrm{a}}$ \\
\hline 2 & 736 & $3.71^{\mathrm{b}}$ & $3.34^{\mathrm{a}}$ & $27.22^{\mathrm{b}}$ & $22.39^{\mathrm{b}}$ & $170.57^{\mathrm{a}}$ \\
\hline 3 & 1631 & $3.87^{\mathrm{a}}$ & $3.15^{\mathrm{b}}$ & $28.07^{\mathrm{c}}$ & $29.91^{\mathrm{c}}$ & $149.57^{\text {ad }}$ \\
\hline 4 & 7381 & $3.63^{\mathrm{c}}$ & $3.34^{\mathrm{a}}$ & $26.72^{\mathrm{b}}$ & $24.74^{\mathrm{d}}$ & $135.28^{\mathrm{bd}}$ \\
\hline 5 & 5458 & $4.12^{\mathrm{d}}$ & $3.22^{\mathrm{c}}$ & $27.35^{\mathrm{b}}$ & $25.97^{\mathrm{e}}$ & $129.82^{\mathrm{b}}$ \\
\hline 6 & 3683 & $3.71^{\mathrm{b}}$ & $3.34^{\mathrm{a}}$ & $30.87^{\mathrm{d}}$ & $26.27^{\mathrm{e}}$ & $194.94^{\mathrm{c}}$ \\
\hline 7 & $3.66^{\mathrm{b}}$ & $3.35^{\mathrm{a}}$ & $28.12^{\mathrm{c}}$ & $23.18^{\mathrm{a}}$ & $152.01^{\text {ad }}$ \\
\hline 8 & $3.48^{\mathrm{e}}$ & $3.21^{\mathrm{c}}$ & $27.97^{\mathrm{c}}$ & $23.27^{\mathrm{a}}$ & $144.01^{\mathrm{d}}$ \\
\hline 9 & 3709 & $3.14^{\mathrm{b}}$ & $26.74^{\mathrm{b}}$ & $24.32^{\mathrm{d}}$ & $154.81^{\text {ad }}$ \\
\hline 10 & 3635 & $3.91^{\mathrm{a}}$ & $3.15^{\mathrm{b}}$ & $33.49^{\mathrm{e}}$ & $29.24^{\mathrm{f}}$ & $140.76^{\mathrm{d}}$ \\
\hline 11 & 2446 & $4.12^{\mathrm{d}}$ & $3.43^{\mathrm{d}}$ & $26.20^{\mathrm{b}}$ & $28.51^{\mathrm{g}}$ & $155.69^{\mathrm{a}}$ \\
\hline $\mathrm{F}$ & 4976 & $460.95^{* *}$ & $\mathbf{2 1 3 . 8 9 ^ { * * }}$ & $\mathbf{2 6 3 . 7 7 ^ { * * }}$ & $318.46^{* *}$ & $\mathbf{1 8 . 2 5 8 ^ { * * }}$ \\
\hline
\end{tabular}

a,b,c,d,e,f,g Means within the same column with different superscripts differ significantly $(\mathrm{P}<0.01)$

significant differences: * $\mathrm{P}<0.05$; ${ }^{* *} \mathrm{P}<0.01$;

Table 3. Effect of parity on milk fat and protein content, daily milk yield, milk urea concentration and days open

\begin{tabular}{ccccccc}
\hline Lactation & $\mathrm{N}$ & Fat $(\%)$ & Protein (\%) & DMY $(\mathrm{kg})$ & MU (mg dL & DO (days) \\
\hline 1 & 17899 & $3.80^{\mathrm{a}}$ & $3.28^{\mathrm{a}}$ & $25.77^{\mathrm{a}}$ & $25.26^{\mathrm{a}}$ & $151.89^{\mathrm{a}}$ \\
\hline 2 & 13364 & $3.75^{\mathrm{b}}$ & $3.31^{\mathrm{b}}$ & $28.15^{\mathrm{b}}$ & $25.24^{\mathrm{a}}$ & $150.94^{\mathrm{a}}$ \\
\hline $3+$ & 15052 & $3.77^{\mathrm{c}}$ & $3.28^{\mathrm{a}}$ & $27.77^{\mathrm{c}}$ & $25.04^{\mathrm{b}}$ & $153.36^{\mathrm{a}}$ \\
\hline $\mathrm{F}$ & & $11.1^{* *}$ & $20.00^{* *}$ & $269.2^{* *}$ & $3.14^{*}$ & 0.29 \\
\hline
\end{tabular}

a,b,c Means within the same column with different superscripts differ significantly $(\mathrm{P}<0.01)$

significant differences: ${ }^{*} \mathrm{P}<0.05$; ${ }^{* *} \mathrm{P}<0.01$ 
As presented in Table 5, a positive relationship between MU and milk production traits and days open interval could be noticed. Positive association between MU and milk production traits and days open interval was confirmed by the coefficient of correlation (r). Positive significant coefficient of correlation $(\mathrm{P}<0.01)$ was determined between $\mathrm{MU}$ and observed milk parameters and days open.

Milk protein content was the highest when MU values were between $20-25 \mathrm{mg} \mathrm{dL}^{-1}$. Protein content decreased when MU was higher than $25 \mathrm{mg} \mathrm{dL}$. Konjačić et al. (2010) also found that milk protein percentage was the highest when MU values ranged from 15.0 to $25.0 \mathrm{mg} \mathrm{dL}^{-1}$. The concentrations of MU above $30.0 \mathrm{mg} \mathrm{dL}^{-1}$ had a negative effect on milk protein content. Johnson and Young (2003) detected higher protein content (3.4 \%) when MUN values ranged from 6.01 to $8.0 \mathrm{mg} \mathrm{dL}^{-1}$. Most recent researches reported negative correlation between MUN and protein content (Godden et al.; 2001; Hojman et al., 2004; Yoon et al., 2004; Abdouli et al., 2008), but in our research a positive coefficient was determined $(\mathrm{r}=0.0257)$ also Bendelja et al. (2011) found a positive correlation. Rajala-Schultz and Saville (2003) did not report any significant relation.

Milk fat content increased with increasing MU level. A significant and positive correlation coefficient $(r=0.1091)$ was determined between the fat content and the urea concentration in milk. Abdouli et al (2008) and Bendelja et al. (2011) found positive correlation between milk fat content and MUN. Hojman et al. (2004) explained that higher content of neutral detergent fibres in forage may increase milk fat content and at the same time caused increased urea concentration, due to the high degradability of its proteins. Negative relation between milk fat and MUN was reported by Johnson and Young (2003) and Konjačić et al. (2010).

The lowest DMY (26.33 kg) had cows with MU between $15-20 \mathrm{mg} \mathrm{dL}^{-1}$, and the highest DMY (28.26 kg) had cows with the highest MU (>35 mg/dL). Daily milk yield was positively correlated $(r=0.0512)$ with MU. Positive association

Table 4. Effect of season on milk fat and protein content, daily milk yield, milk urea concentration and days open

\begin{tabular}{ccccccc}
\hline Season & $\mathrm{N}$ & MM (\%) & Protein $(\%)$ & DMY $(\mathrm{kg})$ & MU (mg dL & DO (days) \\
\hline 1 & 10729 & $3.84^{\mathrm{a}}$ & $3.38^{\mathrm{a}}$ & $27.91^{\mathrm{a}}$ & $25.34^{\mathrm{a}}$ & $161.38^{\mathrm{a}}$ \\
\hline 2 & 9491 & $3.77^{\mathrm{b}}$ & $3.22^{\mathrm{b}}$ & $28.17^{\mathrm{b}}$ & $26.93^{\mathrm{b}}$ & $150.64^{\mathrm{b}}$ \\
\hline 3 & 12147 & $3.66^{\mathrm{c}}$ & $3.15^{\mathrm{c}}$ & $27.32^{\mathrm{c}}$ & $27.11^{\mathrm{b}}$ & $133.58^{\mathrm{b}}$ \\
\hline 4 & 13948 & $3.84^{\mathrm{a}}$ & $3.38^{\mathrm{a}}$ & $25.59^{\mathrm{d}}$ & $22.19^{\mathrm{c}}$ & $167.18^{\mathrm{a}}$ \\
\hline $\mathrm{F}$ & & $\mathbf{1 2 6 . 0 ^ { * * }}$ & $\mathbf{9 4 4}^{* *}$ & $170.2^{* *}$ & $954.21^{* *}$ & $\mathbf{2 8 . 9 3 ^ { * * }}$ \\
\hline
\end{tabular}

a,b,c,d Means within the same column with different superscripts differ significantly $(\mathrm{P}<0.01)$

significant differences: ${ }^{*} \mathrm{P}<0.05 ;{ }^{* *} \mathrm{P}<0.01$

Table 5. The effect of MU group on examined milk parameters and days open and coefficient of correlations (r) between MU and analysed variables

\begin{tabular}{ccccccccc}
\hline MU group / Trait & I & II & III & IV & V & VI & VII & r \\
\hline $\mathrm{N}$ & 2056 & 3687 & 7213 & 10299 & 10611 & 7021 & 5428 & 46315 \\
\hline Protein $\%$ & $3.18^{\mathrm{a}}$ & $3.25^{\mathrm{b}}$ & $3.29^{\mathrm{c}}$ & $3.31^{\mathrm{c}}$ & $3.30^{\mathrm{c}}$ & $3.30^{\mathrm{c}}$ & $3.28^{\mathrm{d}}$ & $0.0257^{* *}$ \\
\hline Fat $\%$ & $3.47^{\mathrm{a}}$ & $3.64^{\mathrm{b}}$ & $3.72^{\mathrm{c}}$ & $3.75^{\mathrm{c}}$ & $3.81^{\mathrm{d}}$ & $3.88^{\mathrm{e}}$ & $3.92^{\mathrm{f}}$ & $0.1091^{* *}$ \\
\hline DMY kg & $27.04^{\mathrm{a}}$ & $26.49^{\mathrm{b}}$ & $26.33^{\mathrm{b}}$ & $26.60^{\mathrm{b}}$ & $27.24^{\mathrm{a}}$ & $27.81^{\mathrm{c}}$ & $28.26^{\mathrm{d}}$ & $0.0512^{* *}$ \\
\hline $\mathrm{N}$ & 221 & 375 & 668 & 873 & 856 & 586 & 478 & 4057 \\
\hline Days open $^{1}$ & $135.59^{\mathrm{a}}$ & $141.15^{\mathrm{ab}}$ & $151.81^{\mathrm{bc}}$ & $156.63^{\mathrm{cd}}$ & $151.43^{\mathrm{bc}}$ & $150.75^{\mathrm{bc}}$ & $163.18^{\mathrm{d}}$ & $0.0589^{* *}$ \\
\hline $\mathrm{N}$ & 34 & 310 & 773 & 1151 & 1028 & 567 & 194 & 4057 \\
\hline Days open $^{2}$ & $72.62^{\mathrm{a}}$ & $114.06^{\mathrm{b}}$ & $147.17^{\mathrm{c}}$ & $161.78^{\mathrm{c}}$ & $161.06^{\mathrm{c}}$ & $157.89^{\mathrm{c}}$ & $128.28^{\mathrm{b}}$ & $0.0702^{* *}$ \\
\hline
\end{tabular}

${ }^{1} \mathrm{MU}$ value on the closest test day the successful breeding; ${ }^{2}$ mean of monthly MU values of cows before conceptions;

${ }^{*} \mathrm{P}<0.05,{ }^{*} \mathrm{P}<0.01$

$\mathrm{a}, \mathrm{b}, \mathrm{c}, \mathrm{d}, \mathrm{e}, \mathrm{f}$ Means within the same row with different superscripts differ significantly $(\mathrm{P}<0.01)$ 
between daily milk yield and MUN had also been reported by Carrlson et al. (1995), Godden et al. (2001), Johnson and Young (2003) and Konjačić et al. (2010). Hojman et al. (2004) determined the correlation coefficient between the above stated parameters $(\mathrm{r}=0.17)$. Positive correlation between daily milk yield and MU was expected because cows with higher milk production were fed diets richer in protein component.

Between milk urea concentration and the open days a significant $(\mathrm{P}<0.01)$ and positive coefficient of correlation $\left(r=0.0589\left(\mathrm{DO}^{1}\right) ; \mathrm{r}=0.0702\left(\mathrm{DO}^{2}\right)\right)$ was determined. In our research we observed the effect of MU on days open in two ways. At first we categorized cows into seven groups based on MU values on the day control closest to a successful conception. Cows with the lowest urea concentration in milk $\left(<10 \mathrm{mg} \mathrm{dL}^{-1}\right)$ had the lowest day open interval (135.59 days) and cows with MU higher than $35 \mathrm{mg} \mathrm{dL}^{-1}$ had the longest day open interval (163.18 days). In the second way we categorized cows into seven groups based on mean MU values from milk controls before a successful conception. In this way cows with lower mean MU values $\left(<10 \mathrm{mg} \mathrm{dL}^{-1}\right)$ also had the lowest days open interval (72.62 days), but cows with mean MU values between 20.01-25.00 $\mathrm{mg} \mathrm{dL}^{-1}$ had the longest day open interval (161.78 days). Some other authors also reported negative MUN influence on fertility dairy cows (Butler et al., 1996; Arunvipas et al., 2007; König et al. 2008, Mucha and Strandberg, 2011). Yoon et al. (2004) reported a positive phenotypic association between urea and days open, stating that cows with MUN concentrations $>18 \mathrm{mg} \mathrm{dL}^{-1}$ had more days open than cows with MUN concentrations $<18 \mathrm{mg} \mathrm{dL}^{-1}$. Mitchell et al. (2005) found a positive genetic correlation of wet chemistry MUN with days open of 0.21 . Other authors did not find correlation between MUN and fertility (Garcia-Bojalil et al., 1998; Godden et al., 2001; Kenny et al., 2001; Kenny et al., 2002).

The biological mechanisms explaining the possible relationship between urea concentrations and fertility are still not well defined. One possible physiological explanation for negative correlation between MUN and fertility was given by Godden et al. (2001). They reported that increased ammonia or urea concentration decreased uterine $\mathrm{pH}$ and reduced conception rates.

\section{Conclusion}

Based on the research results, the following conclusions can be made:

- MU concentration and other analysed variables varied depending on season, parity and farm;

- There are positive and statistically significant correlations between the milk urea concentration and milk fat and protein content, as well as between milk urea concentration and milk yield;

- The results of this study indicate that increasing MU levels appear to be negatively associated with fertility of dairy cows and thus increase the days open.

Maintaining and monitoring MU in dairy herds provide an opportunity to formulate the dietary protein constituency that optimizes nitrogen utilization for milk production and avoids possible negative effects on herd fertility.

\section{Utjecaj nehranidbenih čimbenika na razinu uree u mlijeku i njezina povezanost $s$ parametrima mliječnosti $i$ plodnosti u mliječnih stada u Vojvodini}

\section{Sažetak}

Svrha rada bila je utvrditi odnos između uree mlijeka i plodnosti mliječnih krava na temelju terenskih podataka. U radu je utvrđen utjecaj okolišnih čimbenika na razinu uree u mlijeku (MU) te odnos između MU i dnevne količine mlijeka, mliječne masti i bjelančevina. Podaci su prikupljeni na 11 mliječnih farmi u Vojvodini. Reproduktivni podaci i mjerenja MU utvrđeni su u krava koje su se telile od lipnja 2013. do listopada 2015. godine, a koje su imale uspješnu oplodnju nakon teljenja. Statistička obrada podataka provedena je primjenom metode General Linear Model u programskom paketu Statistica 13. U modelu su kao fiksne varijable uključeni redoslijed laktacije, sezona teljenja, sezona kontrole mlijeka i farma. Značajne razlike $u$ razini MU utvrđene su između farmi $(\mathrm{P}<0,01)$, sezona $(\mathrm{P}<0,01)$ i redoslijeda laktacije $(\mathrm{P}<0,05)$. Utvrđeni su vrlo značajni $(\mathrm{P}<0,01)$ pozitivni odnosi između 
razine MU i proizvodnje mlijeka, sadržaja mliječne masti i bjelančevina, te servisnog razdoblja. Krave s $M U<10 \mathrm{mg} \mathrm{dL}^{-1}$ imale su najkraće servisno razdoblje (135,59 dana), dok su krave s razinom MU $>35 \mathrm{mg} \mathrm{dL}^{-1}$ imale najdulje servisno razdoblje (163,18 dana). Nadalje, krave s najnižim prosječnim MU vrijednostima $\left(<10 \mathrm{mg} \mathrm{dL}^{-1}\right)$ imale su najkraće servisno razdoblje $(72,62$ dana), dok su krave s prosječnom vrijednosti MU 20,01-25,00 $\mathrm{mg} \mathrm{dL}^{-1}$ imale najdulje servisno razdoblje (161,78 dana). Rezultati ovog rada ukazuju da povećanje razine MU negativno utječe na plodnost mliječnih krava.

Ključne riječi: urea u mlijeku, mliječne krave, servis razdoblje, sezona, redoslijed laktacije

\section{References}

1. Abdouli, H., Rekik, B., Haddad-Boubaker, A. (2008): Non-nutritional factors associated with milk urea concentrations under Mediterranean conditions. World Journal of Agricultural Sciences 4 (2), 183-188.

2. Arunvipas P., van Leeuwen J.A., Dohoo I.R., Keefee G.P. (2003): Evaluation of the reliability and repeatability of automated milk urea nitrogen testing. The Canadian Journal of Veterinary Research 67 (1), 60-63.

3. Arunvipas, P., van Leeuwen, J.A., Dohoo, I.R., Leger, E.R., Keefe, G.P., Burton, A.S., Lissemore, K.D. (2007): Milk urea nitrogen negatively affected first service breeding success in commercial dairy cows in Prince Edward Island, Canada. Preventive Veterinary Medicine 82 (1-2), 42-50. https://doi.org/10.1016/j.prevetmed.2007.05.005

4. Bastin, C., Laloux, L., Gillon, A., Miglior, F., Soyeurt, H., Hammami, H., Bertozzi , C., Gengler, N. (2009): Modeling milk urea of Walloon dairy cows in management perspectives. Journal of Dairy Science 92 (7), 3529-3540. https://doi.org/10.3168/jds.2008-1904

5. Bendelja, D., Prpić, Z., Mikulec, N., Ivkić, Z., Havranek. J., Antunac, N. (2011): Milk urea concentration in Holstein and Simmental cows. Mljekarstvo 61 (1), 45-55.

6. Bouwman, A.C., Schopen, G.C.B., Bovenhuis, H., Visker, M.H.P.W., van Arendonk, J. A. M. (2010): Genome-wide scan to detect quantitative trait loci for milk urea nitrogen in Dutch Holstein-Friesian cows. Journal of Dairy Science 93 (7), 3310-3319. https://doi.org/10.3168/jds.2009-2829

7. Broderick, G.A., Clayton, M.K. (1997): A statistical evaluation of animal and nutritional factors influencing concentrations of milk urea nitrogen. Journal of Dairy Science 80 (11), 2964-2971. https://doi.org/10.3168/jds.S0022-0302(97)76262-3
8. Butler W.R., Calaman J.J., Beam S.W. (1996): Plasma and milk urea nitrogen in relation to pregnancy rate in lactating dairy cattle. Journal of Animal Science 74 (4), 858-865. https://doi.org/10.2527/1996.744858x

9. Butler W.R. (2005): Relationships of dietary protein and fertility. Advances in Dairy Technology 17, 159-168.

10. Carlson, J., Pehrson, B. (1993): The relationship between seasonal variations in the concentration of urea in bulk milk and the production and fertility of dairy herds. Journal of the American Veterinary Medical Association 40, 205-212. https://doi.org/10.1111/j.1439-0442.1993.tb00618.x

11. Carlson, J., Bergstrom, J., Pehrson, B. (1995): Variations with breed, age, season, yield, stage of lactation, and herd in the concentration of urea in bulk milk and individual cow milk. Acta Veterinaria Scandinavica 36 (2) 245-254.

12. Carroll, D.J., Barton, B.A., Anderson, G.W., Smith, R.D. (1988): Influence of protein intake and feeding strategy on reproductive performance of dairy cows. Journal of Dairy Science 71 (12), 3470-3481. https://doi.org/10.3168/jds.S0022-0302(88)79953-1

13. Čobanović, K., Kučević, D., Trivunović, S., Plavšić, M. (2015): Variability of milk urea on Vojvodina's dairy farms. VI International Scientific Agricultural Symposium “Agrosym 2015” Jahorina, 16-18 October 2015, Bosnia and Herzegovina, 1665-1671.

14. De Vries, A., Risco, C.A. (2005): Trends and seasonality of reproductive performance in Florida and Georgia dairy herds from 1976 to 2002. Journal of Dairy Science 88 (9), 3155-3165. https://doi.org/10.3168/jds.S0022-0302(05)72999-4

15. Eicher, R., Bouchard, E., Bigras-Poulin, M. (1999): Factors affecting milk urea nitrogen and protein concentrations in Quebec dairy cows. Preventive Veterinary Medicine 39 (1), 53-63. https://doi.org/10.1016/S0167-5877(98)00139-1

16. Elrod, C.C., Butler, W.R. (1993): Reduction of fertility and alteration of uterine $\mathrm{pH}$ in heifers fed excess ruminally degradable protein. Journal of Animal Science 71 (3) 694-701.

17. Fatehi, F., Zali, A., Honarvar, M., Dehghan - Banadaky, M., Young, A.J., Ghiasvand, M., Efekhari, M. (2012): Review of the relationship between milk urea nitrogen and days in milk, parity, and monthly temperature mean in Iranian Holstein cows. Journal of Dairy Science 95 (9), 5156-5163. https://doi.org/10.3168/jds.2011-4349

18. Ferguson, J.K., Chalupa, W. (1989): Interactions of nutrition and reproduction. Impact of protein nutrition on reproduction in dairy cows. Journal of Dairy Science 72 (3), 746-766. https://doi.org/10.3168/jds.S0022-0302(89)79168-2

19. Ferguson J.D., Skidmore, A. (2013): Reproductive performance in a select of dairy herds. Journal of Dairy Science 96 (2), 1269-1289. https://doi.org/10.3168/jds.2012-5805 
20. Garcia-Bojalil, C.M., Staples, C.R., Risco, C., Savio, J.D., Thatcher, W.W. (1998): Protein degradability and calcium salts of long-chain fatty acids in the diets of lactating dairy cows: reproductive responses. Journal of Dairy Science 81 (5), 1385-1395. https://doi.org/10.3168/jds.S0022-0302(98)75702-9

21. Godden, S.M., Kelton D.F., Lissemore, K.D., Walton, J.S., Leslie K.E., Lumsden, J.H. (2001): Milk urea testing as a tool to monitor reproductive performance in Ontario dairy herds. Journal of Dairy Science 84 (1), 1397-1426. https://doi.org/10.3168/jds.S0022-0302(01)70171-3

22. Gustafsson, A.H., Carlson, J. (1993): Effects of silage quality, protein evaluation systems and milk urea content on milk yield and reproduction in dairy cows. Livestock Production Science 37, 91-105. https://doi.org/10.1016/0301-6226(93)90066-Q

23. Hof, G., Vervoorn, M.D., Lenaers, P.J., Tamminga, S. (1997): Milk urea nitrogen as a tool to monitor the protein nutrition of dairy cows. Journal of Dairy Science 80 (2), 3333-3340. https://doi.org/10.3168/jds.S0022-0302(97)76309-4

24. Hojman, D., Kroll O., Adin, G., Gips, M., Hanocchi, B., Ezra E. (2004): Relationships between milk urea and production, nutrition, and fertility traits in Israeli dairy herds. Journal of Dairy Science 87 (4), 1001-1011. https://doi.org/10.3168/jds.S0022-0302(04)73245-2

25. Hojman, D., Gips, M., Ezra, E. (2005): Association between live body weight and milk urea concentration in Holstein cows. Journal of Dairy Science 88 (2) 580-584. https://doi.org/10.3168/jds.S0022-0302(05)72721-1

26. Howard, H.J., Aaleseth, E.P., Adams, G.D., Bush, L.J., Mc New, R.W., Dawson, L.J. (1987): Influence of dietary protein on reproductive performance of dairy cows. Journal of Dairy Science 70 (8), 1563-1571. https://doi.org/10.3168/jds.S0022-0302(87)80184-4

27. ICAR (2014): Recording guidelines. International Committee for Animal Recording.

28. SRPS ISO/IEC 17025 (2006): Opšti zahtevi za kompetentnost laboratorija za ispitivanje i laboratorija za etaloniranje. SL. Glasnik 16/06.

29. ISO 9622 (2013): Milk and liquid milk products Guidelines for the application of mid-infrared spectrometry.

30. Jilek, F., Rehak, D., Volek, J., Štipkova, M., Nemecova, E., Fiedlerova, M., Rajmon, R., Švestkova, D. (2006): Effect of herd, parity, stage of lactation and milk yield on urea concentration in milk. Czech Journal of Animal Science 51 (12), 510-517.

31. Johnson, R.G., Young A.J. (2003): The association between milk urea nitrogen and DHI production variables in Western commercial dairy herds. Journal of Dairy Science 86 (9), 3008-3015. https://doi.org/10.3168/jds.S0022-0302(03)73899-5

32. Jonker, J.S., Kohn, R.A., Erdman, R.A. (1998): Using milk urea nitrogen to predict nitrogen excretion and utilization efficiency in lactating dairy cows. Journal of Dairy Science 81 (10), 2681-2692. https://doi.org/10.3168/jds.S0022-0302(98)75825-4
33. Jonker, J.S., Kohn, R.A., High, J. (2002): Use of milk urea nitrogen to improve dairy cow diets. Journal of Dairy Science 85 (4), 939-946. https://doi.org/10.3168/jds.S0022-0302(02)74152-0

34. Kaufmann, W. (1982): Variation in composition of raw milk with special regard to the urea content. Milchwissenschaft 37 (1), 6-9.

35. Kenny, D.A., Boland, M.P., Diskin, M.G., Sreenan, J.M. (2001): Effect of pasture crude protein and fermentable energy supplementation on blood metabolite and progesterone concentration and embryo survival in heifers. Animal Science 73 (3), 501-511. https://doi.org/10.1017/S1357729800058471

36. Kenny, D.A., Boland, M.P., Diskin, M.G., Sreenan, J.M. (2002): Effect of rumen degradable protein with or without fermentable carbohydrate supplementation on blood me tabolites and embryo survival in cattle. Animal Science 74 (3), 529-537. https://doi.org/10.1017/S1357729800052681

37. Kohn, R.A., French, K.R., Russek-Cohen, E. (2004): A comparison of instruments and laboratories used to measure milk urea nitrogen in bulk-tank milk samples. Journal of Dairy Science 87 (6), 1848-1853. https://doi.org/10.3168/jds.S0022-0302(04)73342-1

38. König, S., Chang, Y.M., Borstel, U.U., Gianola, D., Simianer, H. (2008): Genetic and phenotypic relationships among milk urea nitrogen, fertility and milk yield in Holstein cows. Journal of Dairy Science 91 (11), 4372-4382. https://doi.org/10.3168/jds.2008-1236

39. Konjačić, M., Ivanković, A., Ivkić, Z., Mijić, P., Kelava, N., Ramljak, J., Luković, Z., Kos, I. (2006): Utjecaj sezone i farme na koncentraciju ureje u mlijeku Holstein krava. Stočarstvo 60 (6) 421-426.

40. Larson, S.F., Butler, W.R., Currie, W.B. (1997): Reduced fertility associated with low progesterone postbreeding and increased milk urea nitrogen in lactating cows. Journal of Dairy Science 80 (7), 1288-1295. https://doi.org/10.3168/jds.S0022-0302(97)76058-2

41. Löf, E., Gustafsson, H., Emanuelson, U. (2007): Associations between herd characteristics and reproductive efficiency in dairy herds. Journal of Dairy Science 90 (10), 4897-4907. https://doi.org/10.3168/jds.2006-819

42. Lopez-Gatius, F. (2003): Is fertility declining in dairy cattle? A retrospective study in northeastern Spain. Theriogenology 60 (1), 89-99. https://doi.org/10.1016/S0093-691X(02)01359-6

43. Main breeding organization (2016): Annual report 2015 about implementation of breeding measures in livestock Vojvodina. Department of animal science, Faculty of agriculture. Novi Sad.

44. Melendez, P., Donovan, A., Hernandez, J. (2000): Milk urea nitrogen and infertility in Florida Holstein cows. Journal of Dairy Science 83 (3), 459-463. https://doi.org/10.3168/jds.S0022-0302(00)74903-4 
45. Mitchell, R.G., Rogers, G.W., Dechow, C.D., Vallimont, J.E., Cooper J.B., Sander- Nielsen U., Clay J.S. (2005): Milk urea nitrogen concentration: Heritability and genetic correlations with reproductive performance and disease. Journal of Dairy Science 88 (12), 4434- 4440. https://doi.org/10.3168/jds.S0022-0302(05)73130-1

46. Moore, D.A., Varga, G. (1996): BUN and MUN: urea nitrogen testing in dairy cattle. Compendium on Continuing Education for the Practising Veterinarian 18 (12), 712-720.

47. Mucha, S., Strndberg, E. (2011): Genetic analysis of milk urea nitrogen and relationships with yield and fertility across lactation. Journal of Dairy Science 94 (11), 5665-5672. https://doi.org/10.3168/jds.2010-3916

48. Nêmečková, D., Stádník, L., Čítek, J. (2015): Associations between milk production level, calving interval length, lactation curve parameters and economic results in Holstein cows. Mljekarstvo 65 (4), 243-250.

49. Oltner, R., Emanuelson, M., Wiktorsson, H. (1985): Urea concentration in milk in relation to milk yield, live weight, lactation number and amount and composition of feed given to dairy cows. Livestock Production Science 12 (1), 47-57. https://doi.org/10.1016/0301-6226(85)90039-9

50. Oudah, E.Z.M. (2009): Non genetic factors affecting somatic cell count, milk urea content, test day milk yield and milk protein percent in dairy cattle of Czech Republic using individual test day records. Livestock Research for Rural Development 21 (5) 1-25.

51. Pryce, J.E., Royal, M.D., Garnsorty, M.D., Mao, I.L. (2004): Fertility in the high-producing dairy cow. Livestock Production Science 86 (1), 125-135. https://doi.org/10.1016/S0301-6226(03)00145-3

52. Rajala-Schultz, P.J., Frazer, G.S., (2003): Reproductive performance in Ohio dairy herds in 1990s. Animal Reproduction Science 76 (3-4), 127-142. https://doi.org/10.1016/S0378-4320(02)00243-9

53. Rajala-Schultz, P.J., Saville, W.J.A. (2003): Sources of variation in milk urea nitrogen in Ohio dairy herds. Journal of Dairy Science 86 (5), 1653-1661. https://doi.org/10.3168/jds.S0022-0302(03)73751-5

54. Rajala-Schultz, P.J., Saville, W.J.A., Frazer, G.S., Wittum, T.E. (2001): Association between milk urea nitrogen and fertility in Ohio dairy cows. Journal of Dairy Science 84 (2), 482-489. https://doi.org/10.3168/jds.S0022-0302(01)74498-0

55. Rodriguez, L.A., Stallings, C.C., Herbein, J.H., McGilliard, M.L. (1997): Effect of degradibility of dietary protein and fat on ruminal, blood, and milk components of Jersey and Holstein cows. Journal of Dairy Science 80 (2), 353-363. https://doi.org/10.3168/jds.S0022-0302(97)75945-9
56. Stančić, B. (1988): Reprodukcija domaćih životinja. Institut za stočastvo, Poljoprivredni fakultet, Univerzitet u Novom Sadu.

57. Stoop, W.M., Bovenhuis, H., van Arendonk, J.A.M. (2007): Genetic parameters for milk urea nitrogen in relation to milk production traits. Journal of Dairy Science 90 (4), 1981-1986. https://doi.org/10.3168/jds.2006-434

58. Washburn, S.P., Silvia, W.J., Brown, C.H, McDaniel, B.T., Mcallister, A.J. (2002): Trends in reproductive performance in south-eastern Holstein and Jersey DHI herds. Journal of Dairy Science 85 (1), 244-251. https://doi.org/10.3168/jds.S0022-0302(02)74073-3

59. Wattiaux, M.A., Karg, K.L. (2004): Protein level for alf-alf and corn silage - based diets: I. Lactation response and milk urea nitrogen. Journal of Dairy Science 87 (10), 3480-3491. https://doi.org/10.3168/jds.S0022-0302(04)73483-9

60. Wattiaux, M.A., Nordheim, E.V., Crump, P. (2005): Statistical Evaluation of factors and interactions affecting dairy herd improvement milk urea nitrogen in commercial Midwest dairy herds. Journal of Dairy Science 88 (8), 3020-3035. https://doi.org/10.3168/jds.S0022-0302(05)72982-9

61. Westwood, C.T., Lean, I.J., Kellaway, R.C. (1998): Indications and implications for testing of milk urea in dairy cattle: A quantitative review. Part 2. Effect of dietary protein on reproductive performance. New Zealand Veterinary Journal 46 (4), 123-130. https://doi.org/10.1080/00480169.1998.36076

62. Wittwer, F.G., Gallardo, P., Reyes, J., Opitz, H. (1999): Bulk milk urea concentrations and their relationship with cow fertility in grazing dairy herds in Southern Chile. Preventive Veterinary Medicine 38 (2-3), 159-166. https://doi.org/10.1016/S0167-5877(98)00121-4

63. Wood, G.M., Boettcher, P.J., Jamrozik, J., Jansen, G.B., Kelton, D.F. (2003): Estimation of genetic parameters for concentrations of milk urea nitrogen. Journal of Dairy Science 86 (7), 2462-2469. https://doi.org/10.3168/jds.S0022-0302(03)73840-5

64. Yoon, J.T., Lee, J.H., Kim, C.K., Chung, Y.C., Kim, C.H. (2004): Effects of milk production, season, parity and lactation period on variations of milk urea nitrogen concentrations and milk components of Holstein dairy cows. Asian-Australasian Journal of Animal Sciences 17 (4) 479-484. https://doi.org/10.5713/ajas.2004.479

65. Zadeh-Hossein, N.G., Ardalan, M. (2011): Estimation of genetic parameters for milk urea nitrogen and its relationship with milk constituents in Iranian Holsteins. Livestock Science 135 (2-3), 274-281. https://doi.org/10.1016/j.livsci.2010.07.020 